\title{
Role of Fire in the Global Land Water Budget during the Twentieth Century due to Changing Ecosystems ${ }^{\mathscr{b}}$
}

\author{
FANG LI \\ International Center for Climate and Environmental Sciences, Institute of Atmospheric Physics, Chinese \\ Academy of Sciences, Beijing, China \\ DAVID M. LAWRENCE \\ National Center for Atmospheric Research, ${ }^{\mathrm{a}}$ Boulder, Colorado
}

(Manuscript received 20 June 2016, in final form 24 October 2016)

\begin{abstract}
Fire is a global phenomenon and the primary form of terrestrial ecosystem disturbance on a global scale. It is tightly coupled with climate, ecosystems, carbon and water cycles, and human activities. Through biomass burning and fire-induced plant-tissue mortality, current and historical fires significantly affect terrestrial ecosystems, which can alter hydrology fluxes. This study provides the first quantitative assessment and understanding about the influence of fire on the global land water budget due to changing terrestrial ecosystems during the twentieth century. This is done by quantifying the difference between twentieth-century fire-on and fire-off simulations using the Community Earth System Model (CESM). Results show that fire significantly reduces the annual evapotranspiration (ET) over the global land by $0.6 \times 10^{3} \mathrm{~km}^{3} \mathrm{yr}^{-1}$ and increases global total of runoff in almost the same quantity, while having almost no impact $\left(0.0 \times 10^{3} \mathrm{~km}^{3} \mathrm{yr}^{-1}\right)$ on annual precipitation amount. Fire also weakens both the significant upward trend in total ET over global land prior to the 1950 s and the downward trend from 1950 to about 1985 by approximately $35 \%$. For the twentiethcentury average, fire impact on ET and runoff is most clearly seen in the tropical savannas, African rain forests, and some boreal forests and southern Asian forests. Fire affects global ET and runoff through reducing vegetation canopy and vegetation height, which interact with fire-induced changes in biogeochemical cycle and result in drier and warmer surface air and higher wind speed. Globally speaking, reducing the vegetation canopy is the main pathway of fire's impact on ET and runoff.
\end{abstract}

\section{Introduction}

Fire is an important Earth system process and the primary form of terrestrial ecosystem disturbance on a global scale (Fosberg et al. 1999; Bowman et al. 2009). Each year, fire leads to around $400 \mathrm{Mha}\left(1 \mathrm{Mha}=10^{4} \mathrm{~km}^{2}\right)$ of land area burned and approximately $2 \mathrm{Pg}$ of carbon emitted to the atmosphere (van der Werf et al. 2010; Randerson et al. 2012; Giglio et al. 2013). Fire is driven by climate, terrestrial ecosystems, carbon and water

Supplemental information related to this paper is available at the Journals Online website: http://dx.doi.org/10.1175/ JCLI-D-16-0460.s1.

${ }^{a}$ The National Center for Atmospheric Research is sponsored by the National Science Foundation.

Corresponding author e-mail: Fang Li, lifang@mail.iap.ac.cn cycles, and human activities, and at the same time it feeds back into these systems (Marlon et al. 2008; Langmann et al. 2009; Tosca et al. 2013; Li et al. 2014). Earlier studies have quantified fire's impact on a certain hydrology flux or in a particular region and ecosystem (Neary et al. 2005; Randerson et al. 2006; Bond-Lamberty et al. 2009; Tosca et al. 2013). However, as a global phenomenon, its impact on global water budget is unknown and the related mechanisms are also unclear. Quantifying and understanding the impact of fire on the land water budget in the context of global change is important to improve our knowledge concerning the role of fire in the Earth system and to support management of fire and water resources, especially since increased fire risk is often an expected consequence of projected climate change in many regions (Hantson et al. 2016).

Fire can alter the land water budget by emitting trace gases and aerosols. The trace gases from biomass 
burning contain not only the key greenhouse gases, but also other trace gases that can change the oxidation capacity of the atmosphere, modify the lifetime of atmospheric methane, and enhance the concentration of ozone (Andreae and Merlet 2001; Ito et al. 2007). Fire is also presently the largest source of primary carbonaceous aerosol mass globally (Andreae and Rosenfeld 2008). There have been several model studies to quantify the global impact of fire emissions. Ward et al. (2012) estimated that fire emissions contributed a present-day radiation forcing of $-0.5 \mathrm{~W} \mathrm{~m}^{-2}$. Based on atmosphere model and satellite-based fire product, Tosca et al. (2013), Clark et al. (2015), and Jiang et al. (2016) reported that fire aerosols can affect global precipitation, surface air temperature, and/or the Hadley circulation. The fire-induced changes in precipitation, temperature, atmospheric circulation, and energy cycle can accompany or lead to the changes in land hydrology (Arora 2002; Wang and Dickinson 2012).

Fire can also modify the land water budget due to changing terrestrial ecosystems (Randerson et al. 2006; Langmann et al. 2009). When fire passes through a region, on average, almost all leaves, over half of tree stems, and $10 \%-15 \%$ of roots are damaged (Arora and Boer 2005; van der Werf et al. 2010). Sometimes, fire even results in whole-plant mortality and the change of vegetation compositions (Chapin et al. 2006; Staver et al. 2011). The fire-induced changes in carbon and nitrogen $(\mathrm{C} / \mathrm{N})$ cycles and vegetation structure and composition may affect land water and heat states and fluxes and climate (Bonan 2008; Bond-Lamberty et al. 2009). Both current and historical fires can affect land ecosystems (Li et al. 2014; Yang et al. 2015; Yue et al. 2016). The lagged effect of historical fires accompanies the whole process of ecosystem regrowth and recovery that can last for a long time and even over a century (Bond-Lamberty et al. 2004; Amiro et al. 2010). Earlier studies regarding the biogeophysical impact of fire on land hydrology were on a site or regional scale (Neary et al. 2005; Amiro et al. 2006; Kang et al. 2006; DeBano 2009; Bond-Lamberty et al. 2009). So far, no study has quantified fire's impact on the global land water budget due to changing terrestrial ecosystems.

An Earth system model including a global fire scheme is a necessary platform for quantifying and understanding the global role of fire in the Earth system, given that the interactions among climate, fire, terrestrial ecosystems, and human activities occur on a wide range of temporal and spatial scales. Recently, Li et al. (2012, 2013, 2014) developed a global fire model that can reasonably simulate global total and temporal and spatial variability of fire, as well as distinguish contributions of contemporary fire carbon emissions from various sources (deforestation fires, agricultural fires, peat fires, and others). In this fire model, the burned-area fraction is determined by climate and weather conditions, vegetation composition and structure, and human activities (including human deforestation rate for deforestation fires; anthropogenic ignitions and fire suppression and agricultural waste management for other nonpeat fires estimated by functions of population density and gross domestic product). After the estimation of the burnedarea fraction, the fire module calculates the changes in $\mathrm{C} / \mathrm{N}$ pools due to biomass and peat burning and fireinduced vegetation mortality. These changes are used to adjust $\mathrm{C} / \mathrm{N}$ pools in land ecosystems. It has become the fire model of the Community Earth System Model (CESM; Oleson et al. 2013) and the Chinese Academy Sciences' Earth System Model (CAS-ESM; Zeng et al. 2014; Wang et al. 2014) and has been introduced into the next version of Beijing Climate Center, Climate System Model (BCC_CSM; W.-P. Li 2015, personal communication). In addition, it was partly used in the Dynamic Land Ecosystem Model (DLEM; Yang et al. 2014), the GFDL Earth System Model (GFDL-ESM; Rabin 2016), and the Canadian Earth System Model (CanESM; Melton and Arora 2016).

The present study provides the first estimates of the fire's impact on the global water budget through fire's impact on terrestrial ecosystems during the twentieth century. It is based on quantitative assessment of the difference in the land water cycle between a CESM1.2 control (fire-on) simulation and a twentieth-century fireoff simulation. In this paper, in section 2 , we introduce the methods and data, including the model platform, experimental design, input data, and evaluation of CESM contemporary global simulations of fire and the water cycle. In section 3, we present CESM twentiethcentury burned-area simulations and quantify the impact of fire on the century-average global total, the spatial pattern, and the temporal variability of annual land water fluxes during the twentieth century. The related mechanisms are analyzed in section 4. Discussion and conclusions appear in section 5 .

\section{Methods and data}

\section{a. Model platform}

The CESM is a global coupled model developed by the National Center for Atmospheric Research (NCAR) that is composed of models simulating Earth's atmosphere, ocean, land, and sea ice (Hurrell et al. 2013). The present study adopts the latest CESMsupported release version, CESM1.2. We analyze the twentieth-century transient coupled simulations from 
Community Atmosphere Model, version 5 (CAM5; atmosphere component), Community Land Model, version 4.5 (CLM4.5), with its carbon-nitrogen biogeochemical module (BGC) (CLM4.5-BGC; land component) and using the fire module from CLM, version 5, with BGC (CLM5-BGC; to be released soon), and the Community Ice Code, version 4 (CICE4; sea ice component).

Relative to its earlier version (CAM4), CAM5 includes new boundary layer, shallow convection, radiation, and microphysics schemes, fully interactive aerosols, and updates for the spectral element dynamical core (Neale et al. 2012; Meehl et al. 2013). CICE4 is an upgraded version of the Community Sea Ice Model, version 5 (CSIM5), which was based on CICE3, and uses the energy conserving thermodynamics of Bitz and Lipscomb (1999) and has four ice layers and one snow layer in each thickness category (Holland et al. 2012). CLM4.5 is the latest version of the CLM family of models (Oleson et al. 2013). Its carbon-nitrogen biogeochemical version is CLM4.5-BGC, which succeeds CLM4 with a carbon-nitrogen $(\mathrm{CN})$ biogeochemical model (CLM4-CN; Lawrence et al. 2011) with updates to photosynthesis, soil biogeochemistry, fire dynamics, cold region hydrology, lake modeling, and the biogenic volatile organic compounds model. CLM4.5BGC integrates biophysical and biogeochemical processes of the land surface into a single and physically consistent framework, and has the capacity to model the impact of transient land-cover and land-use change. It represents the land surface as a hierarchy of subgrid types, including vegetated, glacier, lake, and urban land units. A vegetated land unit is further divided into plant functional types (PFTs) that share a soil column.

In the real world and in CAM5-CLM4.5-BGCCICE4, the terrestrial large-scale water balance, on an annual time scale, can be simply written as

$$
\operatorname{Pr}=\mathrm{ET}+\mathrm{RO},
$$

given that the changes in land water storage as snow and soil moisture are small. Precipitation $(\mathrm{Pr})$ is the snow and rain that has fallen from atmosphere to land (input); evapotranspiration (ET), the water vapor evaporated and plant-transpired from land to atmosphere (output), is a vital link between land energy, water, and carbon cycles; and runoff (RO) is total runoff from surface and subsurface (also called drainage) as well as glaciers, wetlands, and lakes, representing the water flowing from land to ocean (output). ET is the sum of vegetation transpiration (Et; the moisture carried from plant roots to atmosphere through leaf stomata), evaporation of precipitation intercepted by the canopy $(\mathrm{Ec})$, and soil evaporation (Es):

$$
\mathrm{ET}=\mathrm{Et}+\mathrm{Ec}+\mathrm{Es} .
$$

The fire module includes four components: agricultural fires in cropland, deforestation and degradation fires in the tropical closed forests, nonpeat fires outside cropland and tropical closed forests, and peat fires (see Fig. S1 in the supplemental material). The version of the fire module utilized in this study is that in CLM4.5BGC (Li et al. 2012, 2013, 2014) except with a modified calculation of the dependence of fire occurrence and spread on fuel wetness for nonpeat fires outside cropland and tropical closed forests and three parameters recalibrated or tuned (see the appendix). For agricultural fires, burned-area fraction is determined by fuel availability, socioeconomic factors, and prescribed fire seasonality. The burned-area fraction due to deforestation and degradation fires is determined by human deforestation rate, weather and climate conditions, and fuel load. Nonpeat fires outside cropland and tropical closed forests are calculated by a processbased model of intermediate complexity. It is affected by climate and weather conditions, vegetation composition and structure, and human activities represented by nonlinear functions of population density and economic situations. The burned-area fraction of peat fires depends on climate conditions and area fraction of peat exposed to the air. After the calculation of burned-area fraction, fire impact is estimated, including biomass and peat burning, which emits $\mathrm{C} / \mathrm{N}$ to the atmosphere directly, and plant-tissue mortality, which leads to $\mathrm{C} / \mathrm{N}$ transferred from $\mathrm{C} / \mathrm{N}$ pools of live tissues to those of litter, dead stem, and dead coarse roots. Estimates of biomass burning and plant-tissue mortality are based on PFT-dependent combustion completeness factors and fire mortality factors (see Table S1 in the supplemental material).

\section{b. Experimental design}

All simulations (Fig. 1) were conducted using CESM with spatial resolution using a $1.9^{\circ}$ latitude $\times 2.5^{\circ}$ longitude finite-volume grid for the atmosphere and land components combined with the $1^{\circ}$ displaced pole grid (gx1v6) for the sea ice component (f19_g16 configuration) and a temporal resolution of $30 \mathrm{~min}$.

First, a transient run of CAM5-CLM4.5-BGCCICE4 with the fire module from CLM5-BGC from 1850 to 2004 was forced by the 1850-2004 time-varying $\mathrm{CO}_{2}$ concentration, nitrogen deposition, land-use and land-cover change, population density data, and sea surface temperature (SST). The 1850-2004 transient run 


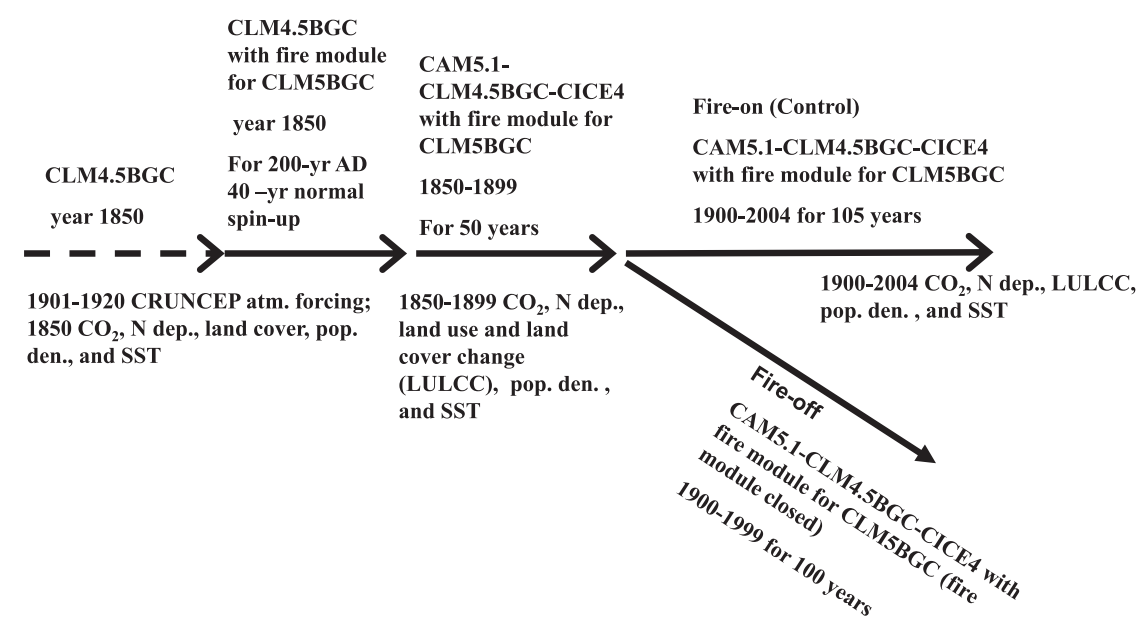

FIG. 1. Experiment design. Dashed line refers to simulations completed prior to this study. The difference between 1900-99 fire-on and fire-off simulations is used to quantify the fire impact.

started from an 1850 equilibrium (spinup) state of CLM4.5-BGC with fire module from CLM5-BGC (will be released this year). The 1850-99 simulation was taken as the spinup of the coupling model, and simulation since 1900 was used as the control simulation (i.e., fireon simulation).

The 1850 spinup run of the land model was forced by repeatedly cycling the 20-yr (1901-20) atmospheric reanalysis data from the CRU climatology with the diurnal cycle and daily variability of the NCEP-NCAR reanalysis (referred to as CRUNCEP forcing), and the land cover, $\mathrm{CO}_{2}$ concentration, nitrogen deposition, and population density at their 1850 values. This equilibrium was obtained by running the land model with accelerated decomposition (AD) spinup mode for 200 years followed by the normal mode for 40 years from equilibrium of the default CLM4.5-BGC.

Second, a twentieth-century fire-off simulation was branched from the control simulations in 1900. The only difference between fire-on and fire-off simulations was that the fire is switched off during the twentieth century in the fire-off simulation. The difference between the fire-on and fire-off simulations represented the fire effect.

Fire affects the climate in two main ways: 1) through emissions of trace gases and aerosols and 2) through alterations to terrestrial ecosystem states and functioning (see the introduction). The present study focuses on the latter. In the present model setup, biomass burning and vegetation-tissue mortality changes $\mathrm{C} / \mathrm{N}$ cycles that interact with vegetation structure [e.g., leaf area index (LAI) and vegetation height (Veg. H)]. Fire-induced change in vegetation structure may lead to the modification in land surface water and heat states and fluxes (e.g., ET and runoff), and also affect the vegetation growth and climate (e.g., precipitation), which may, in turn, feeds back to the fire regime (through changing fuel load and fuel combustibility) and water cycle. It should be kept in mind that the impact of fire emissions is not within the scope of the present study, so that the prescribed fire emissions are the same for both the fire-on and fire-off simulations. Moreover, the biogeography component (DV) in CLM4.5-BGC is inactive, so fire's impact via fireinduced change in vegetation distribution is not included. In addition, similar to most other global land models and dynamic global vegetation models, in CLM4.5-BGC, change in root biomass does not affect the rooting depth and root distribution profile.

\section{c. Input data}

All input data are provided with CESM1.2 (NCAR 2014). The prescribed 1850-2004 annual $\mathrm{CO}_{2}$ concentration data come from observations; nitrogen deposition data come from simulations of the CESM atmospheric chemistry and transport model (Hurrell et al. 2013). Annual land-use and land-cover change (LULCC) data for 1850-2005 (Lawrence et al. 2012) are based on version 1 of the Land-Use History A product (LUHa.v1; Hurtt et al. 2006). The 1850-2004 annual population density data are derived from the Database of the Global Environment, version 3.1 (HYDEv3.1; Klein Goldewijk et al. 2010), prior to 1990 and the Gridded Population of the World, version 3 (GPWv3; CIESIN 2005), after 1990. The 1850-2012 monthly SST data are based on the Hadley Centre Sea Ice and Sea 
TABLE 1. Comparison of CESM simulations (fire-on) with benchmarks for present-day burned area (Mha $\mathrm{yr}^{-1}$ ) and land $\mathrm{Pr}$, ET, and RO $\left(10^{3} \mathrm{~km}^{3} \mathrm{yr}^{-1}\right)$. S-Cor is the global spatial correlation coefficient between simulations and benchmarks with a spatial resolution of $1.9^{\circ}$ lat $\times 2.5^{\circ}$ lon. An asterisk indicates that the Pearson correlation passed the Student's $t$ test at the 0.05 significance level. ET-diag is the merged synthesis product from $7 \mathrm{ET}$ datasets based on satellite and/or in situ observations; ET-all is the merged synthesis product based on a total of 40 distinct datasets (besides the 7 ET datasets used in ET-diag, it includes 29 ET datasets calculated via land surface models driven with observations-based forcing and 4 outputs from atmospheric reanalysis). ET-diag and ET-all benchmarks are expressed as mean plus or minus std dev. RO is the average land precipitation from CPC, GPCPv2, and CRU TS3.23 minus the mean of ET in Mueller et al. (2013).

\begin{tabular}{|c|c|c|c|c|}
\hline Variables & Period & CESM & Benchmarks & S-Cor \\
\hline Burned area & 1997-2004 & 452 & $\begin{array}{l}\text { GFED4 (Giglio et al. 2013): } 357 \\
\text { GFED4s (van der Werf et al. 2016; Randerson et al. 2012): } 511\end{array}$ & $\begin{array}{l}0.56 * \\
0.62 *\end{array}$ \\
\hline Pr (no Antarctic) & 1989-2004 & 116 & $\begin{array}{l}\text { CPC (Chen et al. 2002): } 108 \\
\text { GPCPv2.2 (Adler et al. 2003; Huffman et al. 2009): } 113 \\
\text { CRU TS3.23 (Harris et al. 2014): } 104\end{array}$ & $\begin{array}{l}0.77 * \\
0.87 * \\
0.84 *\end{array}$ \\
\hline ET (no Antarctic) & 1989-2004 & 74 & $\begin{array}{l}\text { LandFluxEVAL (Mueller et al. 2013): } \\
\text { ET-diag: } 72 \pm 25 \\
\text { ET-all: } 69 \pm 26\end{array}$ & $\begin{array}{l}0.91 * \\
0.93^{*}\end{array}$ \\
\hline RO (no Antarctic) & 1989-2004 & 42 & $\begin{array}{l}35 \text { (CPC-GPCP-CRU land Pr - ET-diag) } \\
39 \text { (CPC-GPCP-CRU land Pr - ET-all) }\end{array}$ & $\begin{array}{l}0.64 * \\
0.64 *\end{array}$ \\
\hline
\end{tabular}

Surface Temperature (HadISST). Other datasets necessary for running the model are described in Oleson et al. (2013) and Neale et al. (2012). All of the input data are automatically regridded to the resolution of the model running by CESM1.2 (NCAR 2014).

\section{d. Model evaluation}

We briefly evaluate the present-day simulations of burned area, land precipitation, evapotranspiration, and runoff against benchmarks. As shown in Table 1, CESM can overall reasonably simulate the global total and spatial patterns of contemporary fire and the land water cycle.

The simulated 1997-2004 global burned area ( $452 \mathrm{Mhayr}^{-1}$ ) is between the $357 \mathrm{Mha} \mathrm{yr}^{-1}$ of the fourth-generation Global Fire Emissions Database (GFED4; Giglio et al. 2013) and the $511 \mathrm{Mha} \mathrm{yr}^{-1}$ of GFED4s (a version with small fires included; van der Werf et al. 2016; Randerson et al. 2012). GFED4 and GFED4s are the latest versions of the GFED family which is a satellite-based (MODIS) fire product and commonly used to evaluate global fire modeling. The CESM also model the spatial pattern of the burnedarea fraction skillfully (Table 1), reproducing a high burned-area fraction in tropical savannas, a moderate fraction in northern Eurasia and southern Asia, and a low fraction in deserts and humid forests, similar to GFED4 and GFED4s (see Fig. S2 in the supplemental material).

The CESM-simulated global total and spatial distribution of land precipitation is generally close to the gauge-based CPC data (Chen et al. 2002), CRU time series version 3.23 data (TS3.23; Harris et al. 2014), and satellite-based GPCP version 2.2 data (GPCPv2.2) over land (Adler et al. 2003; Huffman et al. 2009). Compared with observations, CESM underestimates precipitation in the southeastern United States and South America, but shows a wet bias in the northern North America, central and northern China, and Australia (see Fig. S3 in the supplemental material). The CESM-simulated ET (Antarctic excluded) is $74 \times 10^{3} \mathrm{~km}^{3} \mathrm{yr}^{-1}$ within the range of the GEWEX LandFluxEVAL project ET-merged synthesis product (Mueller et al. 2013) based on satellite and in situ observations (ET-diag) and based on all 40 distinct datasets (ET-all, including seven ET datasets used in ET-diag, 29 datasets calculated via land surface models, and four outputs from atmospheric reanalysis). The global spatial correlation between CESM simulations and the ET-diag (ET-all) are 0.91 (0.93), significant at a 0.05 level. The spatial distribution of bias in ET simulations is similar to that for precipitation, but with smaller magnitude (see Fig. S4 in the supplemental material). The simulated global total of runoff (Antarctic excluded) is approximately $10 \%$ higher than benchmarks (Table 1 ) and global continental discharge of $37 \times 10^{3} \mathrm{~km}^{3} \mathrm{yr}^{-1}$ mainly based on streamflow data from the world's largest 921 rivers (Dai and Trenberth 2002).

\section{Results}

\section{a. Simulated burned area during the twentieth century}

The average global burned area of CLM4.5 over 1900-99 is $489 \mathrm{Mhayr}^{-1}$, close to the estimate of $500 \mathrm{Mha} \mathrm{yr}^{-1}$ by Mouillot and Field (2005) based on published data, data on land-use practices, qualitative reports, and local studies such as tree-ring analysis. 
The long-term trend of the simulated global burned area exhibits a significant downward trend of $-1.6 \mathrm{Mha} \mathrm{yr}^{-2}$ before about 1970 at the level of 0.05 based on the Mann-Kendall trend test, and does not show an obvious long-term trend for the following decades (Fig. 2a). The changepoint of long-term trend $(\sim 1970)$ is detected using the Standard normal homogeneity test, Pettitt test, and Buishand range test analyses (Wijngaard et al. 2003) of $n$-yr running linear trends $(n=10,11, \ldots, 25)$ at a significance level of 0.05 . The simulated sharp decline before about 1970 is consistent with the trend of fire activities reconstructed by Marlon et al. (2008) from charcoal records and by Wang et al. (2010) based on CO records in the ice core, which may be due to the increase of human fire suppression with rapid population growth and the expansion of agricultural land (Marlon et al. 2008, from CLM4.5-BGC offline run). The long-term change since about 1970 is in the range of trends shown in the earlier reconstructions from Marlon et al. (2008), Wang et al. (2010), and Ferretti et al. (2005) based on methane $\left(\mathrm{CH}_{4}\right)$ records in the ice core, and Mouillot and Field (2005).

For the twentieth century, CESM simulates a high burned-area fraction in tropical savannas and southern Asia, a moderate fraction in northern Eurasia and the Rocky Mountains, and a low fraction in arid regions resulting from low fuel availability and in humid forests because of low fuel combustibility (Fig. 2b). The global spatial pattern of burned areas is similar to that presented in Mouillot and Field (2005), except for underestimation in tropical savannas in northern Australia and shrub land in eastern Russia.

\section{b. Role of fire in the terrestrial water budget}

\section{1) Century-Averaged global total}

For the 1900-99 average of the global land total, fire significantly reduces annual ET by $0.6 \times 10^{3} \mathrm{~km}^{3} \mathrm{yr}^{-1}$ (1\%) (Table 2), close to the decrease resulting from land-use and land-cover change $\left(0.76 \times 10^{3} \mathrm{~km}^{3} \mathrm{yr}^{-1}\right)$ estimated by Boisier et al. (2014). Meanwhile, fire increases runoff by $0.6 \times 10^{3} \mathrm{~km}^{3} \mathrm{yr}^{-1}(1.3 \%)$, which is qualitatively supported by Neary et al. (2005), who showed that fire generally increased runoff in most ecosystems. However, the impact of fire on global annual precipitation is limited, similar to the previous estimates about the global impact of land-cover change [Pitman et al. 2009, the Land-Use and Climate, Identification of Robust Impacts (LUCID) intercomparison project]. The above fire-induced changes of water fluxes indicate that the impact of fire is to allow more water go back to ocean through stream and river discharges and less water vapor be transported from land to ocean in the atmosphere.

The fire-induced ET change can be explained by the changes in its three components. Through biomass burning and postfire plant-tissue mortality, fire significantly reduces vegetation transpiration by $1.5 \times 10^{3} \mathrm{~km}^{3} \mathrm{yr}^{-1}$ and canopy evaporation by $0.5 \times 10^{3} \mathrm{~km}^{3} \mathrm{yr}^{-1}$, but increases soil evaporation by $1.4 \times 10^{3} \mathrm{~km}^{3} \mathrm{yr}^{-1}$ (Table 2).

\section{2) SPATial PATtERN}

As shown in Fig. 3a, fire significantly decreases ET over tropical savannas and some tropical deciduous forests over southern Asia because of fire-induced decrease in vegetation transpiration and canopy evaporation (Figs. 4a,b), although it is partly offset by the increase in soil evaporation due to fire (Fig. 4c). For most boreal forests, the fire-induced change in three ET components almost offset each other, thus showing a limited impact of fire on the total ET (Fig. 3a), similar to the findings of Bond-Lamberty et al. (2009) for the central Canadian boreal forests. For equatorial African rain forests, the significant increase in ET mainly results from the increase in transpiration (Fig. 4a). In total, 16\% of global land area shows a statistically significant change in ET, while the individual ET components change significantly over a broader area $(25 \%, 24 \%$, and $25 \%$ for transpiration, canopy evaporation, and soil evaporation, respectively). For fire-induced ET change per area burned (see Fig. S5 in the supplemental material), the maximum is still in the tropics as shown in the global picture (Fig. 3a). The secondary peak is mainly caused by the forest fires in northern Eurasia. Because ET in these forests is generally smaller than ET in the tropical savannas (Fig. S4), the second peak is much weaker than the first one, different from the situation of fire carbon loss per burned area shown in Ward et al. (2012).

The change in precipitation is negligible over most postfire regions (Fig. 3c), which is supported by site observations of DeBano (2009). Only 5\% land area shows a statistically significant precipitation change, which is the area expected by chance at a 0.05 significance level. Nonetheless, the $5 \%$ impact is similar to the biogeophysical impact of land-cover change (Findell et al. 2007; Gotangco Castillo and Gurney 2013). As expected, the spatial pattern of runoff change due to fire (Fig. 3b) is similar to that of ET (Fig. 3a) but with opposite sign. There is $20 \%$ of land area with significant fire-induced runoff change. The decrease in fire-induced runoff over the closed forests of equatorial Africa is attributed to the fire-induced decrease in precipitation and increase in ET.

As shown in Fig. 3c, there is a significant reduction in precipitation over the closed forests of equatorial Africa and an increase over some tropical Africa savannas. This 

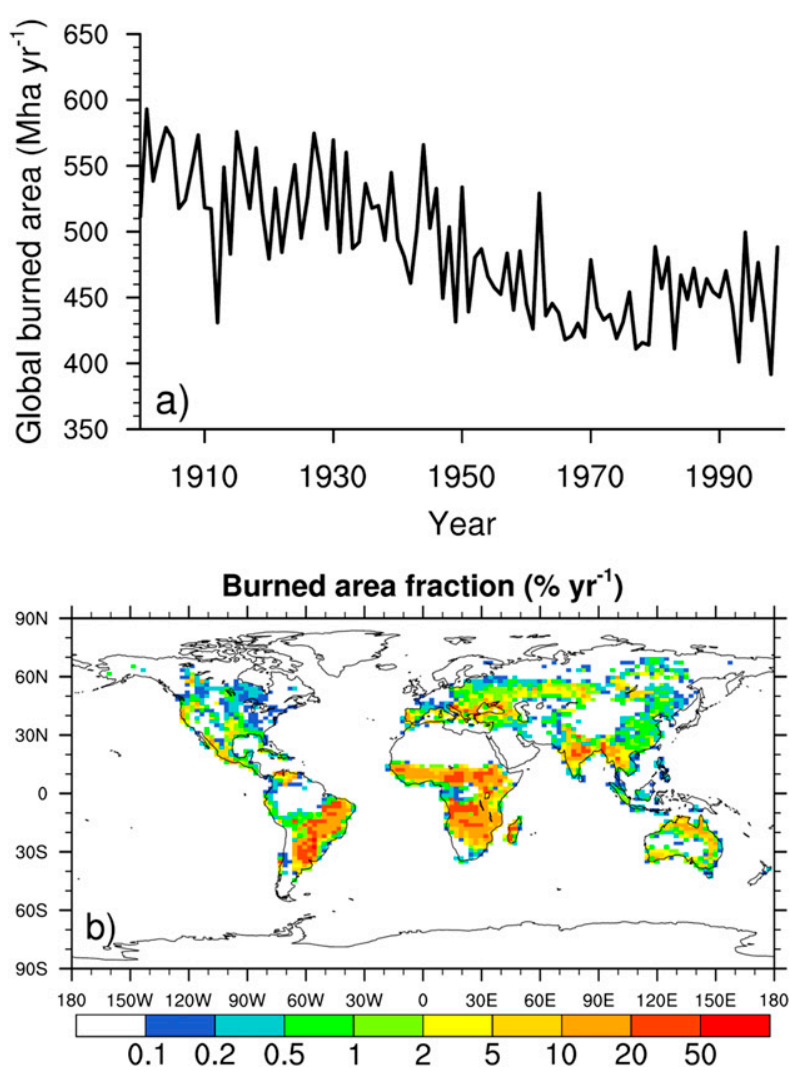

FIG. 2. (a) Historical variability of global total of annual burned area and (b) global spatial distribution of average annual burnedarea fraction in the twentieth century simulated by CESM. In (a), the downward trend before about 1970 is significant at the level of 0.05 based on the Mann-Kendall trend test.

is owing to the local thermal circulation anomalies that are forced by fire-induced significant warming to the south and north regions of the equatorial Africa. Two thermal forcing-driven ascending branches over the tropical African savannas converge toward the equator, leading to an anomalous descending motion in between over equatorial Africa (Fig. 5). The former enhances the convection in tropical African savannas, hence increasing precipitation. The latter suppresses the local upward vertical motion in the equatorial Africa, which leads to the reduction in precipitation. The suppressed upward vertical motion also decreases the low-level cloud cover (figure not shown). The lower coverage of low-level cloud leads to higher solar radiation and thus higher leaf temperature. Correspondingly, transpiration, the absolutely dominant term in ET, increases over equatorial Africa (Fig. 4a).

\section{3) Temporal Variability}

As shown in Fig. 6a, fire generally reduces global ET. The reduction was significantly enhanced $\left(-0.025 \times 10^{3} \mathrm{~km}^{3} \mathrm{yr}^{-2}\right)$ prior to about 1950 , but waned $\left(0.021 \times 10^{3} \mathrm{~km}^{3} \mathrm{yr}^{-2}\right)$ from the 1950 to 1985 .
The changepoints of long-term trends are detected using the same method for global burned area in section 3a. The trends in the ET difference between fireon and fire-off simulations are opposite to those of ET in the fire-off simulation $\left(0.065 \times 10^{3} \mathrm{~km}^{3} \mathrm{yr}^{-2}\right.$ prior to the $1950 \mathrm{~s}$ and $-0.062 \times 10^{3} \mathrm{~km}^{3} \mathrm{yr}^{-2}$ from 1950 to 1985; both are significant), indicating that fire tends to weaken the long-term ET trends. A quantitative comparison between the long-term trends in the fire-on simulation $\left(0.039 \times 10^{3} \mathrm{~km}^{3} \mathrm{yr}^{-2}\right.$ before the $1950 \mathrm{~s}$ and $-0.041 \times 10^{3} \mathrm{~km}^{3} \mathrm{yr}^{-2}$ from 1950 to 1985 ; both are significant) and those in the fire-off simulation shows that fire weakens both the long-term trends in ET by approximately $35 \%$. After 1985 , there is no significant long-term trend in ET for fire-on and fire-off simulations and their difference.

ET difference between fire-on and fire-off simulations (i.e., the fire-induced absolute change) shown in Fig. 6a includes the information of ET variability itself. To exclude the effect from the background ET, we further investigate the relative fire-induced changes in ET and ET components (Fig. 7). Note that fire's impact on vegetation is caused not only by current fires, but also by historical fires, which can last for decades or longer and largely vary with biome (Peterson 2002). The lagged impact of historical fires is the main component of fire's accumulated effect on ecosystems so that the fireinduced decline in LAI and vegetation height is intensified with time (Fig. $7 ;-0.053 \% \mathrm{yr}^{-1}$ for LAI and $-0.048 \% \mathrm{yr}^{-1}$ for vegetation height, significant at a 0.05 level) even though fire activities decline sharply before about 1970 (Fig. 2a). The reduction of LAI and vegetation height is intensified with time, as is the decrease of canopy evaporation $\left(-0.046 \% \mathrm{yr}^{-1}\right)$ and transpiration $\left(-0.042 \% \mathrm{yr}^{-1}\right)$ and the increase of soil evaporation $\left(+0.081 \% \mathrm{yr}^{-1}\right)$ due to fire (Fig. 7). As a consequence of three ET components offseting each other, the average (long-term trend) of ET relative change is $-0.91 \%\left(-0.033 \% \mathrm{yr}^{-1}\right)$ prior to the $1950 \mathrm{~s}$ and $-0.60 \%\left(0.028 \% \mathrm{yr}^{-1}\right)$ from 1950 to 1985 . Based on mathematical derivation, the trend in ET difference is $[\gamma] \beta+\delta[\mathrm{ET}]$, where $\gamma$ is the fire-induced relative change in ET, and $\delta$ is its trend; $\beta$ is the trend of ET variability itself; and square brackets indicate a time mean. For the trend in ET difference, the contribution from the ET variability itself; that is (i.e., $[\gamma] \beta)$ is only $2.4 \%(1.8 \%)$ prior to the 1950 (from 1950 to 1985), and the contribution from fire-induced relative change (i.e., $\delta[\mathrm{ET}]$ ) is more than $97 \%$ because [ET] is much larger than $[\gamma], \beta$, and $\delta$ even though $\delta$ is small. Thus, ET variability itself is not important for fire's impact on the trend in ET, the relative change resulting from fire's accumulated effects on ecosystems not only determines the sign of impact 
TABLE 2. Difference $\left(10^{3} \mathrm{~km}^{3} \mathrm{yr}^{-1}\right)$ in global annual ET, RO, land Pr, and three ET components: Et, Ec, and Es between fire-on and fire-off simulations in the twentieth century. Values in parentheses indicate difference relative to fire-off (\%). Asterisks indicate that the difference in the mean between fire-on and fire-off simulations passed the Student's $t$ test at $\alpha=0.05$ significance level.

\begin{tabular}{cl}
\hline \hline Variables & Fire-on - fire-off \\
\hline ET & $-0.6(-1 \%)^{*}$ \\
RO & $+0.6(+1.3 \%)^{*}$ \\
Pr & $+0.0(+0 \%)$ \\
Et & $-1.5(-4 \%)^{*}$ \\
Ec & $-0.5(-4 \%)^{*}$ \\
Es & $+1.4(+5 \%)^{*}$ \\
\hline
\end{tabular}

(i.e., fire weakens the ET trends because the relative change is negative) but also dominantly controls the magnitude of the weakening.

In addition, the impact of fire tends to decrease precipitation slightly before the 1950s and increase precipitation afterward, but both fire-induced changes are not significant at a 0.05 significance level (not shown). Fire generally increases global runoff, particularly after about 1950 (Fig. 6b), responding to the fire-induced changes in precipitation and ET.

\section{Related mechanisms}

The present study also investigates the mechanisms related to fire's impact on the global land water budget due to changing terrestrial ecosystems (Fig. 8). In CESM, leaf and stem carbon pools are decreased because of biomass burning and fire-induced vegetation mortality, which leads to a significant reduction in vegetation canopy (i.e., LAI) and vegetation height (Fig. 9). Through the coupling between biogeochemistry and biogeophysics, fire-induced changes in vegetation structure decrease carbon input of land ecosystems (see Fig. S6 in the supplemental material), which, in turn, suppresses vegetation growth and postfire recovery of carbon and nitrogen pools and vegetation structure.

The fire-induced reduction in vegetation canopy contributes to the decrease in vegetation transpiration and canopy evaporation resulting from lower leaf area, fewer stomata, and less canopy interception and water storage, and to the increase in soil evaporation by exposing more of the soil to the air and sunlight, consistent with the regional study of Bond-Lamberty et al. (2009). The fire-induced reduction in vegetation height leads to the reduction in land surface roughness. Less rough surface has higher aerodynamic resistance and leaf boundary resistance, and thus generates less turbulence through which water and heat is transferred from the land surface to the atmosphere in CESM (Oleson et al. a) delta ET (16\%)

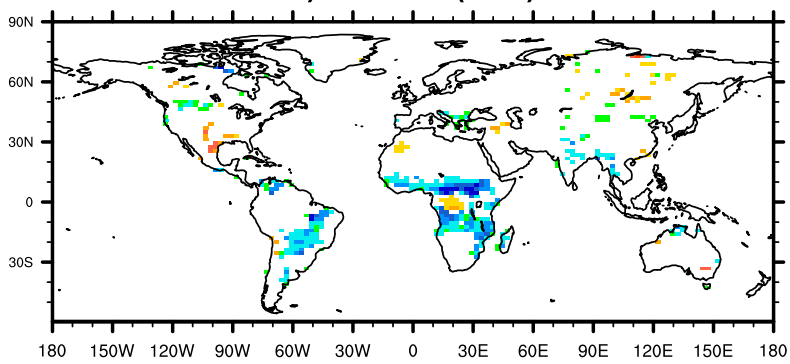

b) delta RO $(20 \%)$

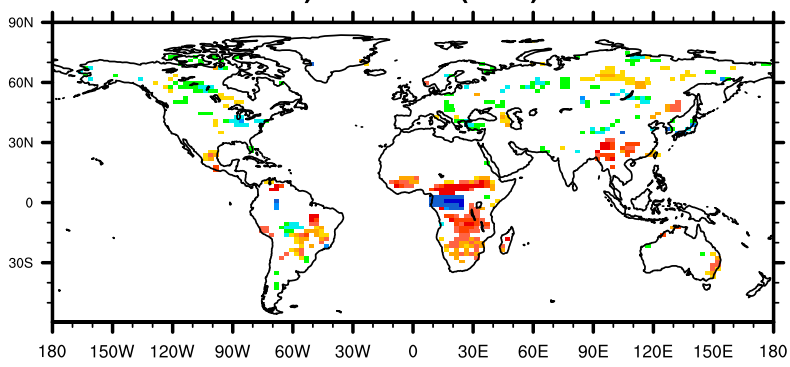

c) delta $\operatorname{Pr}(5 \%)$

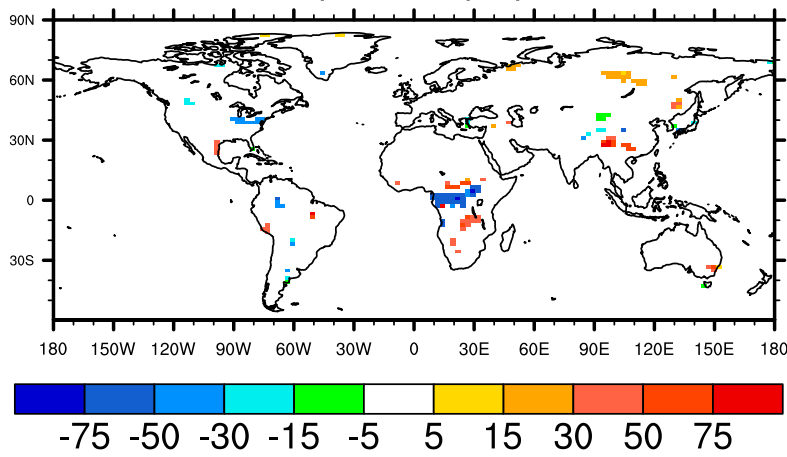

FIG. 3. Changes (fire-on - fire-off) in the annual land (a) ET, (b) RO, and (c) $\operatorname{Pr}\left(\mathrm{mm} \mathrm{yr}^{-1}\right)$. Only areas where changes are significant at $\alpha=0.05$ using the Student's $t$ test are shown. Percent of land area (\%) that exhibits statistically significant changes in water fluxes are also given in parentheses.

2013). This is similar to the impact of reduction in surface roughness resulting from anthropogenic land-cover change (Findell et al. 2007).

Furthermore, the changes in vegetation structure significantly increase wind speed and surface air temperature but decrease surface air relative humidity in most regions where fire affects ET significantly (Table 3). Increased wind speed and warmer and drier surface air can increase water-potential gradient and vapor pressure deficit, hence hastening the water loss from the land surface. Warming can also decrease the non-water-stressed stomatal resistance, and therefore increase transpiration in CESM.

The fire-induced changes in all ET components (Fig. 4) is sign-consistent with that caused by fireinduced reduction in the vegetation canopy, and the 
a) delta Et (25\%)

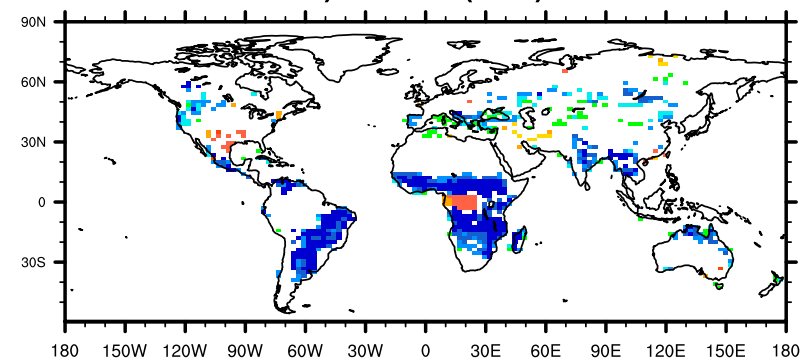

b) delta Ec (24\%)

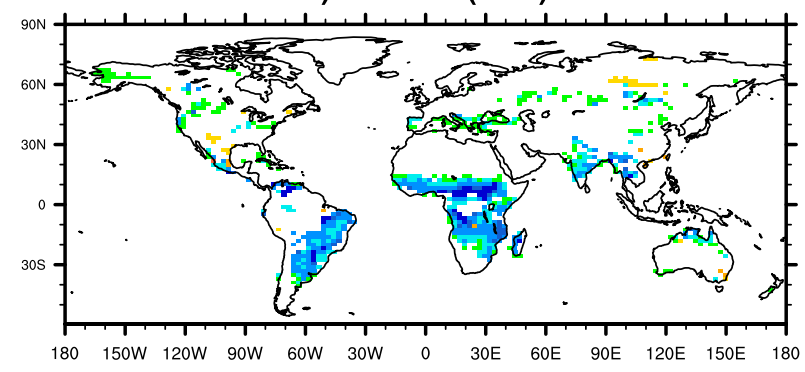

c) delta Es $(25 \%)$

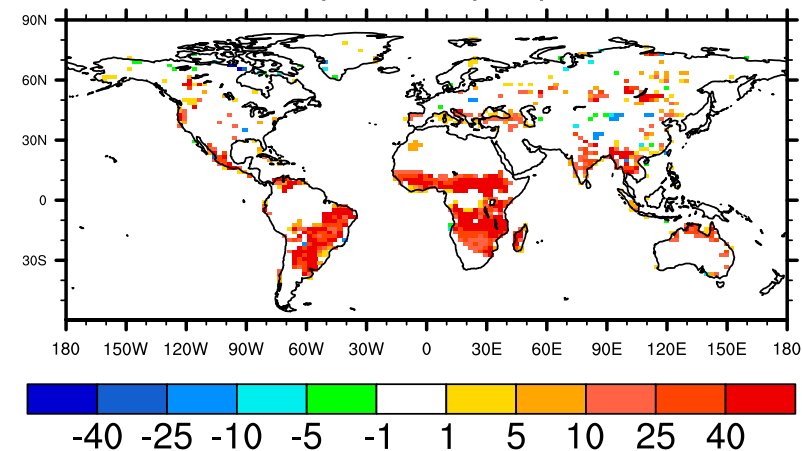

FIG. 4. As in Fig. 3, but for annual (a) Et, (b) Ec, and (c) Es.

reduction of vegetation canopy (i.e., LAI) amplified with time can be also used to explain the long-term trends of the changes in all ET components (Fig. 7). Therefore, globally speaking, reducing the vegetation canopy is a critical pathway of fire's impact on all ET components. The lower surface roughness resulting from fire-induced reduction in vegetation height increases aerodynamic resistance and leaf boundary resistance and thus would tend to decrease ET, but at the same time lower roughness can lead to higher leaf temperature (mainly due to a reduction in sensible heat with less turbulence) and wind speed, which would decrease stomatal resistance and increase ET (especially the transpiration). Its net impact in CESM is to generally increase transpiration and decrease soil evaporation (see Table S2 in the supplemental material), opposite in sign to the fire impact on the two ET components shown in Table 2 and Fig. 4, and is small for canopy evaporation (Table S2). Fire-induced
(a)W(10-30E)

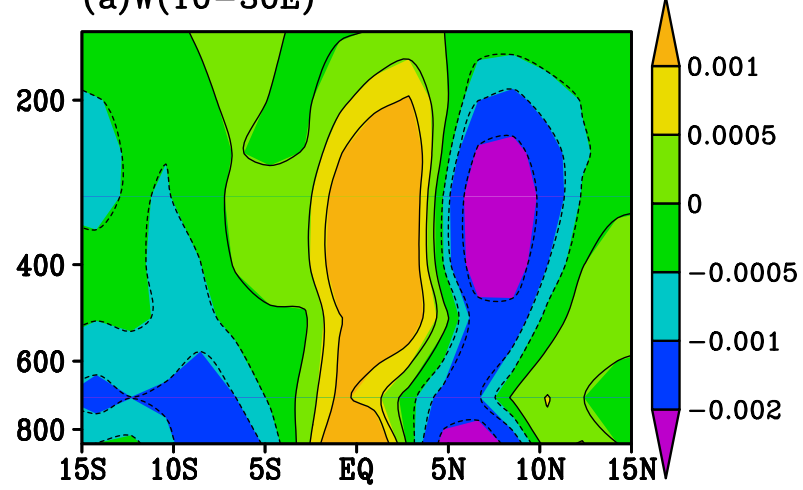

(b)Div \& div winds at $200 \mathrm{hPa}$

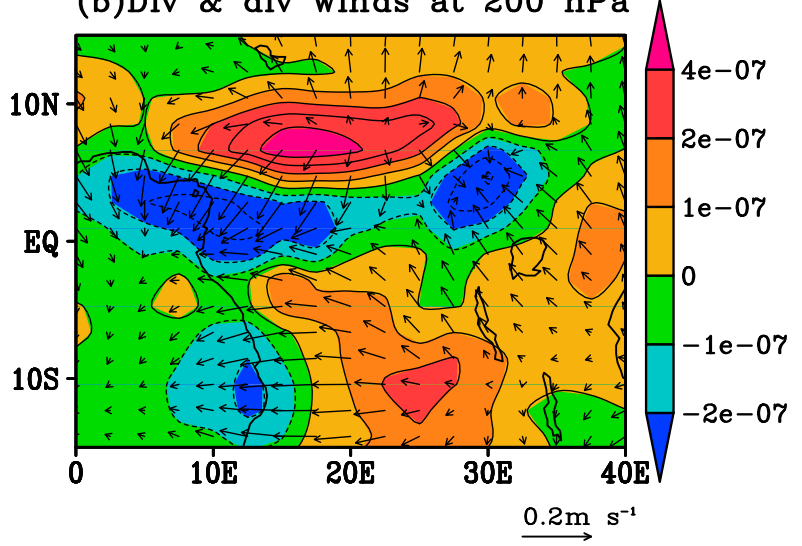

FIG. 5. Fire-induced difference (fire-on - fire-off) in (a) $10^{\circ}-$ $30^{\circ} \mathrm{E}$ zonal-mean annual vertical velocities $\left(\mathrm{Pas}^{-1}\right)$, and (b) divergence (shaded, $\mathrm{s}^{-1}$ ) and divergent wind (vector, $\mathrm{m} \mathrm{s}^{-1}$ ) at $200 \mathrm{hPa}$. Negative value in (a) indicates upward velocity.

changes in environmental conditions tend to increase ET, opposite in sign to fire's impact on ET (Table 2 and Fig. 3a). Because fire's impact on annual precipitation is small in most regions (Fig. 3c) and the impact of fire on runoff because of its influence on soil erosion or soil degradation is not considered here, on the annual scale, fire-induced change in runoff mainly responds to the fire-induced change in ET [Figs. 3a,b; Eq. (1)]. The above analyses suggest that the reduction in the vegetation canopy (thus lower leaf area, fewer stomata, less canopy interception and water storage, and more soil exposed to the air and sunlight) is the main pathway of fire's impact on global ET and runoff.

\section{Conclusions and discussion}

In this study, we utilize CESM to investigate the biogeophysical impact of fire on the global land water budget during the twentieth century. CESM reasonably simulates present-day fire and the land water cycle. The difference between twentieth-century fire-on and fire-off 

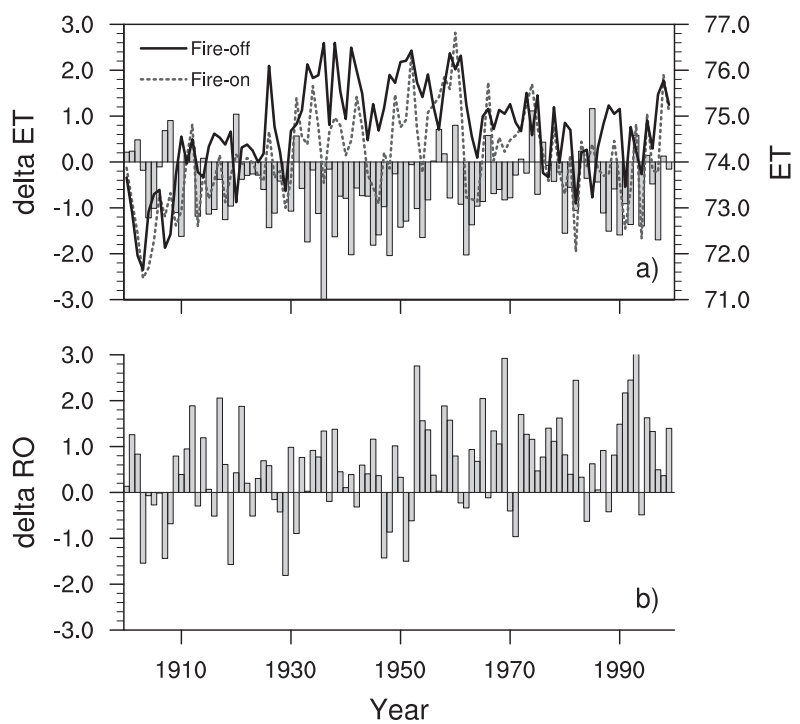

FIG. 6. Difference (bars) in annual land (a) ET and (b) RO between fire-on and fire-off simulations $\left(10^{3} \mathrm{~km}^{3} \mathrm{yr}^{-1}\right)$. In (a), annual land ET (lines, right $y$ axis) for fire-on (dashed) and fire-off (solid) simulations are also shown; the downward (upward) trend prior to the 1950s (from 1950 to about 1985) in ET difference and the upward (downward) trend in ET for both fire-on and fire-off simulations prior to the 1950s (from 1950 to 1985) are significant at the level of 0.05 based on the Mann-Kendall trend test.

simulations is used to quantify and understand fire's effect on historical land water budget. The main findings can be summarized as follows.

- For global total averaged across the twentieth century, fire significantly decreases ET by $0.6 \times 10^{3} \mathrm{~km}^{3} \mathrm{yr}^{-1}$ and increases runoff in almost the same quantity, but has almost no impact on precipitation. The fire-induced change in ET is the result of reduction in transpiration and canopy evaporation, which is partly offset by the rise of soil evaporation over postfire regions.

- For spatial pattern, the impact of fire on ET and runoff is significant over the tropical savannas and closed forests of equatorial Africa and southern Asia, which accounts for $16 \%$ and $20 \%$ of global land area, respectively.

- For temporal variability, the fire-induced reduction in ET was significantly magnified $\left(-0.025 \times 10^{3} \mathrm{~km}^{3} \mathrm{yr}^{-2}\right)$ prior to the 1950 s but waned $\left(0.021 \times 10^{3} \mathrm{~km}^{3} \mathrm{yr}^{-2}\right)$ from the 1950s to about 1985. These trends are opposite in sign to those in ET; quantitatively, the impact of fire is to weaken both the long-term trends in ET by approximately $35 \%$. ET variability itself is not important for fire's impact on the ET trends, lagged ecosystem effects due to historical fires not only determine the sign of fire impact (i.e., weakens ET trends) but also dominantly control the magnitude of the weakening.

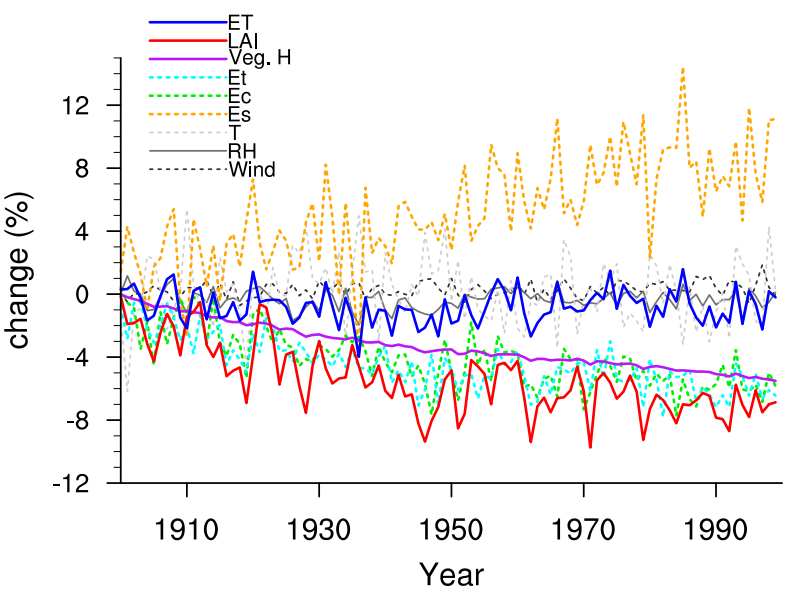

FIG. 7. Changes in ET and its three components, LAI, Veg. H, surface air temperature $T, \mathrm{RH}$, and wind speed due to fire [(fireon - fire-off)/fire-off; \%]. The decrease of LAI, Veg. H, Et, and Ec and the increase of Es and wind speed with time with time are significant at the level of 0.05 based on the Mann-Kendall trend test.

- In the present model setup, fire can affect global ET and runoff through reducing vegetation canopy (i.e., LAI) and vegetation height, which are coupled with fire-induced changes in biogeochemical cycle and lead to the reduction in relative humidity, and increase in surface air temperature and wind speed. Globally speaking, fire affects ET and runoff mainly through reducing the vegetation canopy, which decreases vegetation transpiration and canopy evaporation resulting from lower leaf area, fewer leaf stomata, and less canopy interception and water storage, and increases soil evaporation by exposing more of the soil to the air and sunlight.

Many earlier studies have quantified the impact of various factors on global runoff over the historical period, including the change in atmospheric $\mathrm{CO}_{2}$ concentration (Pitman and Zhao 2000; Gerten et al. 2008), climate change (Gerten et al. 2008), irrigation (Rost et al. 2008; Gerten et al. 2008; Sacks et al. 2009; Döll 2009; Puma and Cook 2010; Döll et al. 2012), and landuse and land-cover change (LULCC; Pitman and Zhao 2000; Gordon et al. 2005; Findell et al. 2007; Bondeau et al. 2007; Gerten et al. 2008; Rost et al. 2008; Lawrence and Chase 2010; Sterling et al. 2013). Based on metaanalysis of these earlier studies, following the method of Sterling et al. (2013), we estimate the impacts of these factors on global runoff and compare them with the fire impact quantified in this study. Note that, for Gordon et al. (2005), Sterling et al. (2013), and Bondeau et al. (2007), $-1.0 \times 10^{3} \mathrm{~km}^{3} \mathrm{yr}^{-1}$ is used to estimate the impact of irrigation. As shown in Fig. 10, the effects of fire and rising $\mathrm{CO}_{2}$ concentration on land ecosystems, climate 


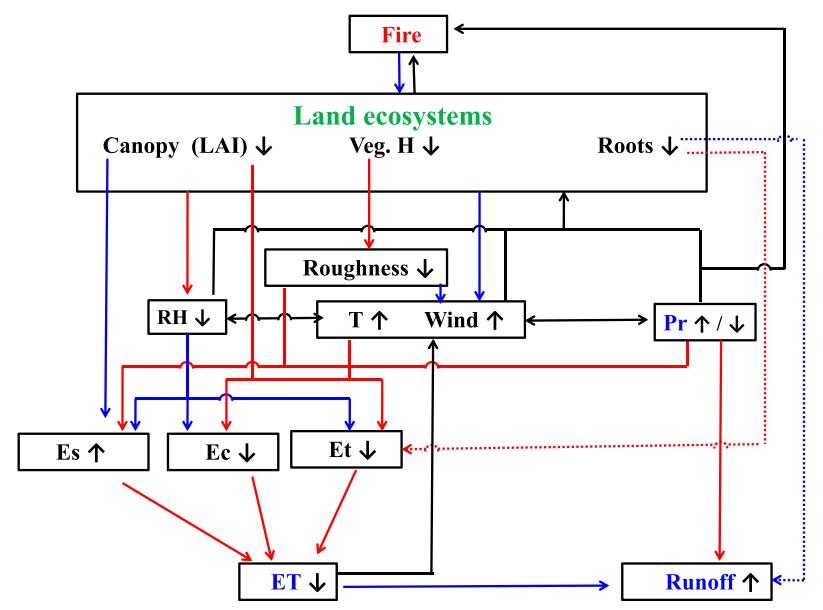

FIG. 8. Schematic of the biogeophysical impact of fire on the water cycle for most regions with significant fire impact. The up and down arrows indicate increase and decrease, respectively; red, blue, and black arrows indicate positive feedbacks (i.e., if higher $a$, then higher $b$, and vice versa), negative feedbacks, and feedbacks dependent on the environment conditions and/or vegetation characteristics, respectively; arrows with dashed lines indicate the processes that are not included in the present study.

change, and LULCC tend to increase runoff, while irrigation reduces runoff. Fire's impact is higher than that from rising $\mathrm{CO}_{2}$ concentration on land ecosystems $(0.5 \pm$ $\left.0.06 \times 10^{3} \mathrm{~km}^{3} \mathrm{yr}^{-1}\right)$ and is more than half of the impact of irrigation $\left(-1 \pm 0.3 \times 10^{3} \mathrm{~km}^{3} \mathrm{yr}^{-1}\right)$, about one-third of the impact of LULCC $\left(1.8 \pm 1.3 \times 10^{3} \mathrm{~km}^{3} \mathrm{yr}^{-1}\right)$ and climate change $\left(2.1 \times 10^{3} \mathrm{~km}^{3} \mathrm{yr}^{-1}\right)$, and is approximately the same as the impact of LULCC when irrigation is included. This highlights the importance of fire in land water budget and implies that fire should be considered in freshwater management.

Several sources of uncertainty in our estimates are worth noting. First, even though CLM4.5-BGC models the fire-induced reduction in root biomass, the impact of root biomass on rooting depth is not modeled, similar to most other global land models and dynamic global vegetation models. Given that reduction in rooting depth can decrease the root-zone water-holding capacity (Findell et al. 2007), the lack of the impact of root biomass on rooting depth may lead to an underestimation of fire-induced decrease in transpiration whose water is taken up from roots and fire-induced increase in runoff. Second, the vegetation distribution in our CESM simulations is prescribed, although other ecosystem characteristics (e.g., LAI, biomass, vegetation height, and carbon fluxes) are dynamically simulated. Therefore, the effect of fire on water budget through changing vegetation distribution is not accounted for in our present estimates, as did in most prior global quantitative studies of fire impact. Earlier studies (San Jose et al. 1998; Murphy and Bowman 2012) reported that fire could limit tree cover in some regions. Without considering fire's impact on vegetation distribution will lead to the underestimation of fire's impact on ET given that regions with higher tree coverage generally have higher ET (Brovkin et al. 2006; Bonan 2008). Third, our fire model does not account for variations in fire intensity which may affect the fire impact over some regions (Rogers et al. 2015). Because of a lack of observations, the processes related to the above three uncertainty sources are hard to be parameterized robustly in global models.

In addition, model biases in CESM are important uncertainty sources that affect our estimates of fire impacts. For example, the wet bias in Canada leads to underestimation of fire there and so underestimation of fire's impact on the water cycle. Regional climate biases make it hard to compare our results quantitatively with site and regional studies (Kang et al. 2006; Amiro et al. 2006; Bond-Lamberty et al. 2009). Furthermore, even though the partitioning of evapotranspiration into transpiration, canopy evaporation, and soil evaporation was improved markedly in CLM4.5 compared with CLM3 (Lawrence et al. 2007, 2011) and is close to the multimodel ensemble in the second GSWP (GSWP-2; Dirmeyer et al. 2006), the percentage of transpiration (44\%) in CESM1.2 may still be underestimated. Recent isotope-based studies estimated transpiration percentage at closer to $60 \%$ (Jasechko et al. 2013; Schlesinger a) delta LAI

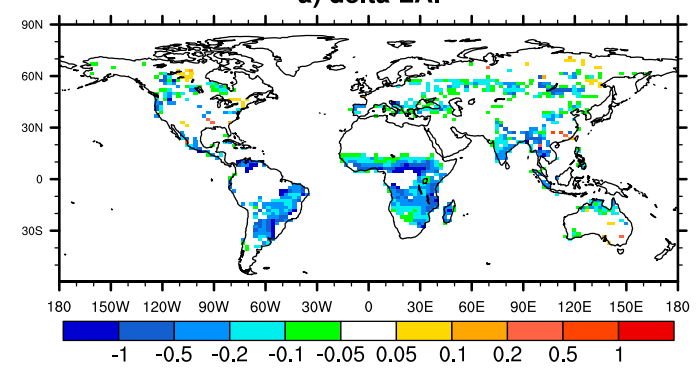

b) delta Veg. $\mathbf{H}$

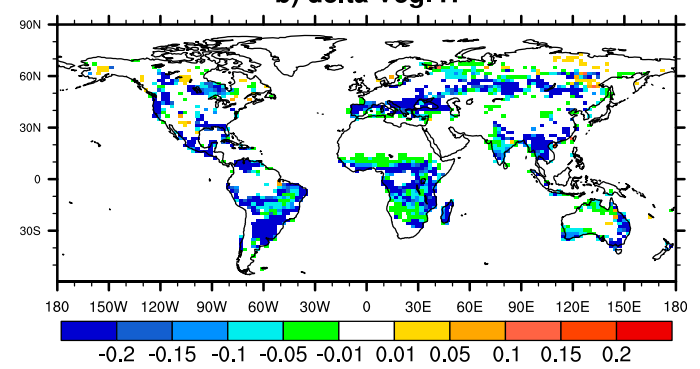

FIG. 9. As in Fig. 3, but for annual (a) LAI $\left(\mathrm{m}^{2} \mathrm{~m}^{-2}\right)$ and (b) Veg. H (m). 
TABLE 3. Area-weighted average and homogeneity of fire-induced change (fire-on - fire-off) of wind speed, temperature $T$, and RH in the regions where fire affects ET significantly $(\alpha=0.05)$. The homogeneity changes are the percent of area where fire-induced change has the same sign with the average.

\begin{tabular}{lccc}
\hline \hline & $\Delta$ Wind & $\Delta T$ & $\Delta \mathrm{RH}$ \\
\hline Average & $+0.03 \mathrm{~m} \mathrm{~s}^{-1}$ & $+0.11^{\circ} \mathrm{C}$ & $-1.25 \%$ \\
Homogeneity & $81 \%$ & $68 \%$ & $78 \%$ \\
\hline
\end{tabular}

and Jasechko 2014). The underestimate of the percentage of ET from transpiration could lead to the underestimate of fire's impact on ET.

Our results show that fire tends to decrease vegetation height (Fig. 9b) and thus increase wind speed (Table 3) because of the reduction in surface roughness, suggesting fire's ability to increase advection and the magnitude of larger-scale flows. In addition, fire-induced changes in land vegetation structure generally lead to lower surface relative humidity and higher surface air temperature (Table 3). Fire-induced drying and warming of surface air and increasing in surface wind speed can increase fire risks and activities [Arora and Boer 2005; Bowman et al. 2009; cf. the CESM fire module (Li et al. 2012, 2013)], which suggests a possible positive feedback loop between fire and climate through fire affecting ecosystem states and functioning. The positive feedback loop may partly explain why the simulated global burned area in CESM atmosphere-land coupling simulation is obviously higher than the CLM4.5-BGC offline simulations.

There are two ways to conduct a twentieth-century fire-off experiment, which are to initialize a twentiethcentury fire-off run from 1) a fire-off equilibrium or 2) a fire-on (control) simulation in 1900, respectively. The difference between the twentieth-century fire-on and fire-off simulations represents the impact of fires happened since $n$ years before 1900 (where $n$ ranges from $<1$ to $>100 \mathrm{yr}$, and varies with biomes) for the former, and the impact of fires during the twentieth century (the period we focused) for the latter. The latter is used here and Li et al. (2014). Landry et al. (2015) also adopted a method similar to ours, in which a twentyfirst-century fire-off run was branched from a control (fire-on) simulation in 2015. The twentieth-century fireoff simulation in the present study includes an adjustment of biosphere to a fire-off equilibrium in the context of global change, similar to the postfire exclusion in the real world. Figure 7 shows that the difference in global ET between fire-on and fire-off simulations is amplified with fire exclusion time prior to about 1950 but waned from 1950 to 1985 . This suggests that, because of the adjustment of biosphere to a fire-off equilibrium included, the fire-induced change in ET prior to about

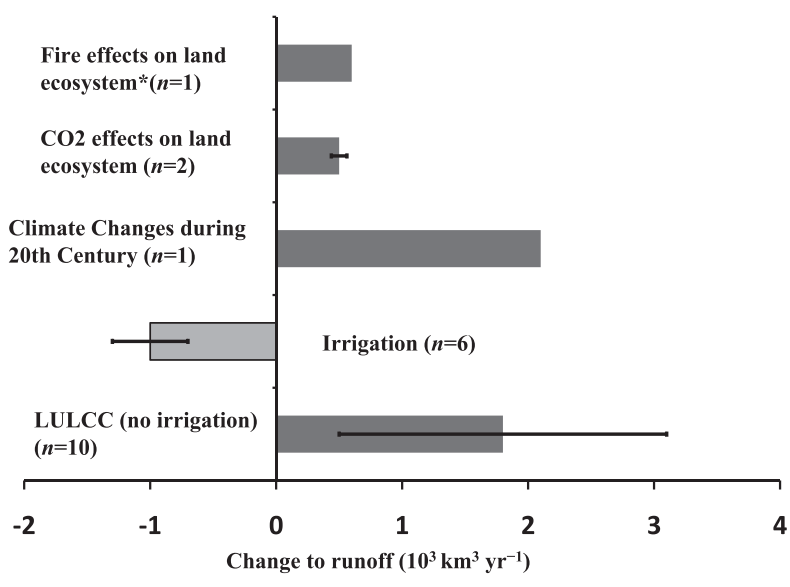

FIG. 10. Estimated impacts of global annual runoff over the historical period due to different factors: changing land ecosystems resulting from fire, changing land ecosystems as a result of changes in atmospheric $\mathrm{CO}_{2}$ concentration, climate change, irrigation, and LULCC. The impact of fire is quantified in the present study, while the impacts of other factors are based on the meta-analysis of earlier literatures following the method of Sterling et al. (2013). Here $n$ refers to the number of estimates; bars and error bars represent the average and one standard deviation of the estimates, respectively.

1950 estimated in the present study may be smaller and its trend prior to about 1950 may be stronger than the estimates if the twentieth-century fire-off simulation is initialized from a fire-off equilibrium.

Acknowledgments. This study is co-supported by the National Natural Science Foundation (41475099) and the Strategic Priority Research Program of the Chinese Academy of Sciences (XDA05110201). We are grateful to E. Kluzek from NCAR for checking and revising the code of fire scheme, S. Levis (now in the Climate Corporation) and P. J. Lawrence from NCAR, Z.-D. Lin from the Institute of Atmospheric Physics, Chinese Academy of Sciences, and R. E. Dickinson from the University of Texas at Austin for helpful discussions. We also thank Dr. Dan Ward and two anonymous reviewers for their valuable comments and suggestions, editor Dr. Jason Evans for handling this paper, G. R. van der Werf from VU University, L. Giglio from the NASA Goddard Space Flight Center, I. Harris from the University of East Anglia, the NOAA/OAR/ESRL PSD, and the ETH Zurich for making their data available. Computing resources were provided by NCAR.

\section{APPENDIX}

\section{Modifications of Fire Module in CLM4.5-BGC}

The fire module from CLM5-BGC is the fire module of CLM4.5-BGC ( $\mathrm{Li}$ et al. 2012, 2013, 2014) with 
modified calculation of dependence of fire occurrence and spread on fuel wetness for the nonpeat fires outside cropland and tropical closed forests.

The dependence of fire occurrence on fuel wetness $f_{m}$ is changed to

$$
f_{m}= \begin{cases}l_{\beta} l_{\mathrm{RH}}, & T>T_{f} \\ 0, & T \leq T_{f}\end{cases}
$$

In Eq. (A1), we assume no fire occurs when the surface air temperature $T$ (in kelvin) is lower than the freezing temperature $T_{f}$, following a global fire model (GlobFIRM; Thonicke et al. 2001), which can improve the fire seasonality modeling in the boreal tundra. The dependence of fuel combustibility on root-zone soil wetness $\beta_{t}$ (ranging from 0 to 1 ) is

$$
l_{\beta}=1-\max \left[0, \min \left(1, \frac{\beta_{t}-0.6}{0.25}\right)\right] .
$$

This change can reduce the overestimation of fire over boreal forests in Eurasia compared with that based on the 0.05-m soil wetness used in CLM4.5-BGC. The dependence of fuel combustibility on relative humidity is the weighted average of real-time relative humidity $l_{\mathrm{RH} 0}$ and 30-day running-mean relative humidity $l_{\mathrm{RH} 30}$ :

$$
l_{\mathrm{RH}}=(1-w) l_{\mathrm{RH} 0}+w l_{\mathrm{RH} 30},
$$

representing the slower desiccation in higher fuel-load region. It is a simplified method to reflect fuel wetness varied with fuel types under the same environment conditions used by Forestry Canada Fire Danger Group (1992) and Thonicke et al. (2010). Here, the fuel-loaddependent weight is $w=\max \left\{0, \min \left[1,\left(L_{f}-2500\right) /\right.\right.$ $(5000-2500)]\}$. Fuel in the regions with fuel load $L_{f}>$ $2500 \mathrm{gC} \mathrm{m}^{-2}$ in CESM generally falls into 100 - and 1000-h fuel classes in Thonicke et al. (2010), where the 100- and 1000-h terms described the order of magnitude of lagged time that fuel wetness changed with surface climate. The use of a 30-day running mean is supported by observations of the 2010 Russian wildfires. The wildfires started in late July and are caused by the strong heat wave with super dry surface air and soil started about one month ago (https://en.wikipedia.org/wiki/ 2010_Russian_wildfires). Compared with only realtime relative humidity used in the fire scheme in CLM4.5-BGC, the introduction of 30-day running-mean relative humidity $(\mathrm{RH})$ can improve the response of fire to dry environment in high-fuel-load regions, especially to extreme drought events. In Eq. (A3), the dependence on real-time relative humidity (ranging from 0 to 1 ) and 30-day running-mean relative humidity $\left(\mathrm{RH}_{30 \mathrm{~d}}\right)$ are
$l_{\mathrm{RH} 0}=1-\max \{0, \min [1,(\mathrm{RH}-0.3) /(0.8-0.3)]\}$ and $l_{\mathrm{RH} 30}=1-\max \left\{0.75, \min \left[1,\left(\mathrm{RH}_{30 \mathrm{~d}} / 0.9\right)\right]\right\}$, respectively. The calculation of $l_{\mathrm{RH} 0}$ is the same as that in CLM4.5-BGC. The parameters in $l_{\mathrm{RH} 30}$ are calibrated using the GFED3 fire product and 30-day running mean of relative humidity from the CRU TS3.23 data.

The dependence of fire spread on fuel wetness $C_{m}$ is simply taken as the square root of the dependence of $f_{m}$ in Eq. (A1):

$$
C_{m}=\sqrt{f_{m}}
$$

representing that fire spreads faster when environment is drier as existing global fire models (Hantson et al. 2016).

In addition, for the CESM atmosphere-land-sea ice coupling simulations, the constants that can control the total burned area of deforestation fires $[b$ in Eq. (5) of $\mathrm{Li}$ et al. (2013)] and boreal peat fires [ $c$ in Eq. (8) of Li et al. (2013)] are recalibrated by the inverse method of $\mathrm{Li}$ et al. (2013). The two constants are changed from 1/1370 (per time step) and $2.1 \times 10^{-5}$ (per time step) in CLM4.5-BGC to $1 / 2200$ (per time step) and $2.0 \times 10^{-5}$ (per time step), respectively. The two constants need be recalibrated when atmospheric forcing or the code of land model is changed. The original values are for observed atmospheric forcing from Qian et al. (2006), while the recalibrated values are for CESM-simulated atmosphere. Furthermore, the potential human ignition frequency [ $\alpha$ in Eq. (5) of Li et al. (2012)], a modeldependent constant, is changed from 0.0035 (count per person per month) in CLM4.5-BGC to 0.0085 (count per person per month) mainly due to the modification in the dependence of fire occurrence on fuel wetness [Eq. (A1)], which is still in a range of $0.001-0.03$ (count per person per month) used in existing global fire models (Li et al. 2012; Mangeon et al. 2016).

\section{REFERENCES}

Adler, R. F., and Coauthors, 2003: The version 2 Global Precipitation Climatology Project (GPCP) monthly precipitation analysis (1979-present). J. Hydrometeor., 4, 1147-1167, doi:10.1175/1525-7541(2003)004<1147:TVGPCP > 2.0.CO;2.

Amiro, B. D., and Coauthors, 2006: Carbon, energy and water fluxes at mature and disturbed forest sites, Saskatchewan, Canada. Agric. For. Meteor., 136, 237-251, doi:10.1016/ j.agrformet.2004.11.012.

_ , and Coauthors, 2010: Ecosystem carbon dioxide fluxes after disturbance in forests of North America. J. Geophys. Res., 115, G00K02, doi:10.1029/2010JG001390.

Andreae, M. O., and P. Merlet, 2001: Emission of trace gases and aerosols from biomass burning. Global Biogeochem. Cycles, 15, 955-966, doi:10.1029/2000GB001382.

, and D. Rosenfeld, 2008: Aerosol-cloud-precipitation interactions. Part 1. The nature and sources of cloud-active aerosols. Earth-Sci. Rev., 89, 13-41, doi:10.1016/j.earscirev.2008.03.001. 
Arora, V. K., 2002: Modeling vegetation as a dynamic component in soil-vegetation-atmosphere transfer schemes and hydrological models. Rev. Geophys., 40, 1006, doi:10.1029/ 2001RG000103.

- , and G. J. Boer, 2005: Fire as an interactive component of dynamic vegetation models. J. Geophys. Res., 110, G02008, doi:10.1029/2005JG000042.

Bitz, C. M., and W. H. Lipscomb, 1999: An energy-conserving thermodynamic model of sea ice. J. Geophys. Res., 104, 15 669-15 677, doi:10.1029/1999JC900100.

Boisier, J. P., N. de Noblet-Ducoudré, and P. Ciais, 2014: Historical land-use induced evapotranspiration changes estimated from present-day observations and reconstructed land-cover maps. Hydrol. Earth Syst. Sci., 18, 3571-3590, doi:10.5194/hessd-11-2045-2014.

Bonan, G. B., 2008: Ecological Climatology: Concepts and Applications. 2nd ed. Cambridge University Press, $550 \mathrm{pp}$.

Bond-Lamberty, B., C. Wang, and S. T. Gower, 2004: Net primary production and net ecosystem production of a boreal black spruce wildfire chronosequence. Global Change Biol., 10, 473 487, doi:10.1111/j.1529-8817.2003.0742.x.

— S. D. Peckham, S. T. Gower, and B. E. Ewers, 2009: Effects of fire on regional evapotranspiration in the central Canadian boreal forest. Global Change Biol., 15, 1242-1254, doi:10.1111/ j.1365-2486.2008.01776.x.

Bondeau, A., and Coauthors, 2007: Modelling the role of agriculture for the 20th century global terrestrial carbon balance. Global Change Biol., 13, 679-706, doi:10.1111/ j.1365-2486.2006.01305.x.

Bowman, D. M. J. S., and Coauthors, 2009: Fire in the Earth system. Science, 324, 481-484, doi:10.1126/science. 1163886.

Brovkin, V., and Coauthors, 2006: Biogeophysical effects of historical land cover changes simulated by six Earth system models of intermediate complexity. Climate Dyn., 26, 587-600, doi:10.1007/s00382-005-0092-6.

Chapin, F. S., III, T. Hollingsworth, D. F. Murray, L. A. Viereck, and M. D. Walker, 2006: Successional processes in the Alaskan boreal forest. Alaska's Changing Boreal Forest, F. S. Chapin III et al., Eds., Oxford University Press, 100-120.

Chen, M., P. Xie, J. E. Janowiak, and P. A. Arkin, 2002: Global land precipitation: A 50-yr monthly analysis based on gauge observations. J. Hydrometeor., 3, 249-266, doi:10.1175/ 1525-7541(2002)003<0249:GLPAYM>2.0.CO;2.

CIESIN, 2005: Gridded population of the world version 3 (GPWv3): Population density grids. Socioeconomic Data and Applications Center (SEDAC), Center for International Earth Science Information Network, Columbia University, accessed 30 April 2015, doi:10.7927/H4XK8CG2.

Clark, S. K., D. S. Ward, and N. M. Mahowald, 2015: The sensitivity of global climate to the episodicity of fire aerosol emissions. J. Geophys. Res. Atmos., 120, 11589-11608, doi:10.1002/ 2015JD024068.

Dai, A. G., and K. E. Trenberth, 2002: Estimates of freshwater discharge from continents: Latitudinal and seasonal variations. J. Hydrometeor., 3, 660-687, doi:10.1175/1525-7541(2002)003<0660: EOFDFC $>2.0 . \mathrm{CO} ; 2$.

DeBano, L. F., 2009: Fire effects on watersheds: An overview. News of the Gila Watershed Partnership, Gila Watershed Partnership, Thatcher, AZ, Vol. 11, 1-5. [Available online at http://www.gwpaz.org/wp-content/uploads/2015/12/March2012-Newsletter.pdf.]

Dirmeyer, P. A., X. A. Gao, M. Zhao, Z. C. Guo, T. K. Oki, and N. Hanasaki, 2006: GSWP-2: Multimodel analysis and impli- cations for our perception of the land surface. Bull. Amer. Meteor. Soc., 87, 1381-1397, doi:10.1175/BAMS-87-10-1381.

Döll, P., 2009: Vulnerability to the impact of climate change on renewable groundwater resources: A global-scale assessment. Environ. Res. Lett., 4, 035006, doi:10.1088/1748-9326/4/3/ 035006.

- , H. Hoffmann-Dobrev, F. T. Portmann, S. Siebert, A. Eicker, M. Rodell, G. Strassberg, and B. R. Scanlon, 2012: Impact of water withdrawals from groundwater and surface water on continental water storage variations. J. Geodyn., 59-60, 143156, doi:10.1016/j.jog.2011.05.001.

Ferretti, D. F., and Coauthors, 2005: Unexpected changes to the global methane budget over the past 2000 years. Science, 309, 1714-1717, doi:10.1126/science.1115193.

Findell, K. L., E. Shevliakova, P. C. D. Milly, and R. J. Stouffer, 2007: Modeled impact of anthropogenic land cover change on climate. J. Climate, 20, 3621-3634, doi:10.1175/JCLI4185.1.

Forestry Canada Fire Danger Group, 1992: Development and structure of the Canadian Forest Fire Behaviour Predictions Systems. Ottawa, Ontario Informational Rep. ST-X-3, 64 pp. [Available online at https://cfs.nrcan.gc.ca/publications?id=10068.]

Fosberg, M. A., and Coauthors, 1999: Strategy for a fire module in dynamic global vegetation models. Int. J. Wildland Fire, 9, 7984, doi:10.1071/WF99007.

Gerten, D., S. Rost, W. von Bloh, and W. Lucht, 2008: Causes of change in 20th century global river discharge. Geophys. Res. Lett., 35, L20405, doi:10.1029/2008GL035258.

Giglio, L., J. T. Randerson, and G. R. van der Werf, 2013: Analysis of daily, monthly, and annual burned area using the fourthgeneration Global Fire Emissions Database (GFED4). J. Geophys. Res. Biogeosci., 118,317-328, doi:10.1002/jgrg.20042.

Gordon, L. J., W. Steffen, B. F. Jönsson, C. Folke, M. Falkenmark, and A. Johannessen, 2005: Human modification of global water vapor flows from the land surface. Proc. Natl. Acad. Sci. USA, 102, 7612-7617, doi:10.1073/pnas.0500208102.

Gotangco Castillo, C. K. G., and K. R. Gurney, 2013: A sensitivity analysis of surface biophysical, carbon, and climate impacts of tropical deforestation rates in CCSM4-CNDV. J. Climate, $\mathbf{2 6}$, 805-821, doi:10.1175/JCLI-D-11-00382.1.

Hantson, S., and Coauthors, 2016: The status and challenge of global fire modelling. Biogeosciences, 13, 3359-3375, doi:10.5194/bg-13-3359-2016.

Harris, I., P. D. Jones, T. J. Osborn, and D. H. Lister, 2014: Updated high-resolution grids of monthly climatic observations-The CRU TS3.10 dataset. Int. J. Climatol., 34, 623-642, doi:10.1002/ joc.3711.

Holland, M. M., D. A. Bailey, B. P. Briegleb, B. Light, and E. Hunke, 2012: Improved sea ice shortwave radiation physics in CCSM4: The impact of melt ponds and aerosols on Arctic sea ice. J. Climate, 25, 1413-1430, doi:10.1175/JCLI-D-11-00078.1.

Huffman, G. J., R. F. Adler, D. T. Bolvin, and G. Gu, 2009: Improving the global precipitation record: GPCP version 2.1. Geophys. Res. Lett., 36, L17808, doi:10.1029/2009GL040000.

Hurrell, J. W., and Coauthors, 2013: The Community Earth System Model: A framework for collaborative research. Bull. Amer. Meteor. Soc., 94, 1339-1360, doi:10.1175/ BAMS-D-12-00121.1.

Hurtt, G. C., S. Frolking, M. G. Fearon, B. Moore, E. Shevliakova, S. Malyshev, S. W. Pacala, and R. A. Houghton, 2006: The underpinnings of land-use history: Three centuries of global gridded land-use transitions, wood-harvest activity, and resulting secondary lands. Global Change Biol., 12, 1208-1229, doi:10.1111/j.1365-2486.2006.01150.x. 
Ito, A., K. Sudo, H. Akimoto, S. Sillman, and J. E. Penner, 2007: Global modeling analysis of tropospheric ozone and its radiative forcing from biomass burning emissions in the twentieth century. J. Geophys. Res., 112, D24307, doi:10.1029/ 2007JD008745.

Jasechko, S., Z. D. Sharp, J. J. Gibson, S. J. Birks, Y. Yi, and P. J. Fawcett, 2013: Terrestrial water fluxes dominated by transpiration. Nature, 496, 347-350, doi:10.1038/nature11983.

Jiang, Y., Z. Lu, X. Liu, Y. Qian, K. Zhang, Y. Wang, and X.-Q. Yang, 2016: Impacts of global wildfire aerosols on direct radiative, cloud and surface-albedo forcings simulated with CAM5. Atmos. Chem. Phys., 16, 14 805-14 824, doi:10.5194/ acp-16-14805-2016.

Kang, S., J. S. Kimball, and S. W. Running, 2006: Simulating effects of fire disturbance and climate change on boreal forest productivity and evapotranspiration. Sci. Total Environ., 362, 85102, doi:10.1016/j.scitotenv.2005.11.014.

Klein Goldewijk, K., A. Beusen, and P. Janssen, 2010: Long term dynamic modeling of global population and built-up area in a spatially explicit way, HYDE 3.1. Holocene, 20, 565-573, doi: $10.1177 / 0959683609356587$.

Landry, J. S., H. D. Matthews, and N. Ramankutty, 2015: A global assessment of the carbon cycle and temperature responses to major changes in future fire regime. Climatic Change, 133, 179-192, doi:10.1007/s10584-015-1461-8.

Langmann, B., B. Duncan, C. Textor, J. Trentmann, and G. R. van der Werf, 2009: Vegetation fire emissions and their impact on air pollution and climate. Atmos. Environ., 43, 107-116, doi:10.1016/j.atmosenv.2008.09.047.

Lawrence, D. M., P. E. Thornton, K. W. Oleson, and G. B. Bonan, 2007: Partitioning canopy evaporation in a GCM: Impacts on land-atmosphere interaction. J. Hydrometeor., 8, 862-880, doi:10.1175/JHM596.1.

—_ and Coauthors, 2011: Parameterization improvements and functional and structural advances in version 4 of the Community Land Model. J. Adv. Model. Earth Syst., 3, M03001, doi:10.1029/2011MS000045. [Available online at www.cesm. ucar.edu/models/cesm1.0/clm/lawrence.clm4.james.2011.pdf.]

Lawrence, P. J., and T. N. Chase, 2010: Investigating the climate impacts of global land cover change in the Community Climate System Model. Int. J. Climatol., 30, 2066-2087, doi:10.1002/joc.2061.

_ - and Coauthors, 2012: Simulating the biogeochemical and biogeophysical impacts of transient land cover change and wood harvest in the Community Climate System Model (CCSM4) from 1850 to 2100. J. Climate, 25, 3071-3095, doi:10.1175/JCLI-D-11-00256.1.

Li, F., X.-D. Zeng, and S. Levis, 2012: A process-based fire parameterization of intermediate complexity in a Dynamic Global Vegetation Model. Biogeosciences, 9, 2761-2780, doi:10.5194/ bg-9-2761-2012.

- S. Levis, and D. S. Ward, 2013: Quantifying the role of fire in the Earth system-Part 1: Improved global fire modeling in the Community Earth System Model (CESM1). Biogeosciences, 10, 2293-2314, doi:10.5194/bg-10-2293-2013.

_- B. Bond-Lamberty, and S. Levis, 2014: Quantifying the role of fire in the Earth system-Part 2: Impact on the net carbon balance of global terrestrial ecosystems for the 20th century. Biogeosciences, 11, 1345-1360, doi:10.5194/bg-11-1345-2014.

Mangeon, S., A. Voulgarakis, R. Gilham, A. Harper, S. Sitch, and G. Folberth, 2016: INFERNO: A fire and emissions scheme for the Met Office's Unified Model. Geosci. Model Dev., 9, 2685-2700, doi:10.5194/gmd-9-2685-2016.
Marlon, J. R., and Coauthors, 2008: Climate and human influences on global biomass burning over the past two millennia. Nat. Geosci., 1, 697-702, doi:10.1038/ngeo313.

Meehl, G. W., and Coauthors, 2013: Climate change projections in CESM1(CAM5) compared to CCSM4. J. Climate, 26, 62876308, doi:10.1175/JCLI-D-12-00572.1.

Melton, J. R., and V. K. Arora, 2016: Competition between plant functional types in the Canadian Terrestrial Ecosystem Model (CTEM) v. 2.0. Geosci. Model Dev., 9, 323-361, doi:10.5194/ gmd-9-323-2016.

Mouillot, F., and C. B. Field, 2005: Fire history and the global carbon budget: A $1^{\circ} \times 1^{\circ}$ fire history reconstruction for the 20th century. Global Change Biol., 11, 398-420, doi:10.1111/ j.1365-2486.2005.00920.x.

Mueller, B., and Coauthors, 2013: Benchmark products for land evapotranspiration: LandFlux-EVAL multi-data set synthesis. Hydrol. Earth Syst. Sci., 17, 3707-3720, doi:10.5194/ hess-17-3707-2013.

Murphy, B. P., and D. M. J. S. Bowman, 2012: What controls the distribution of tropical forest and savanna? Ecol. Lett., 15, 748-758, doi:10.1111/j.1461-0248.2012.01771.x.

NCAR, 2014: Model input data. CESM1.2 Series Public Release, accessed 30 March 2016. [Available online at http://www. cesm.ucar.edu/models/cesm1.2/.]

Neale, R. B., and Coauthors, 2012: Description of the NCAR Community Atmosphere Model (CAM 5.0). NCAR Tech. Note TN-486, 274 pp. [Available online at www.cesm.ucar. edu/models/cesm1.0/cam/docs/description/cam5_desc.pdf.]

Neary, D. G., K. C. Ryan, and L. F. DeBano, 2005: Wildland fire in ecosystems: Effects of fire on soils and water. U.S. Department of Agriculture Rocky Mountain Research Station General Tech. Rep. RMRS-GTR-42-volume 4, 250 pp.

Oleson, K. W., and Coauthors, 2013: Technical description of version 4.5 of the Community Land Model (CLM). NCAR Tech. Note NCAR/TN-503+STR, 420 pp., doi:10.5065/ D6RR1W7M.

Peterson, G., 2002: Contagious disturbance, ecological memory, and the emergence of landscape pattern. Ecosystems, 5, 329338, doi:10.1007/s10021-001-0077-1.

Pitman, A. J., and M. Zhao, 2000: The relative impact of observed change in land cover and carbon dioxide as simulated by a climate model. Geophys. Res. Lett., 27, 1267-1270, doi:10.1029/ 1999GL011029.

- and Coauthors, 2009: Uncertainties in climate responses to past land cover change: First results from the LUCID intercomparison study. Geophys. Res. Lett., 36, L14814, doi:10.1029/2009GL039076.

Puma, M. J., and B. I. Cook, 2010: Effects of irrigation on global climate during the 20th century. J. Geophys. Res., 115, D16120, doi:10.1029/2010JD014122.

Qian, T., A. Dai, K. E. Trenberth, and K. W. Oleson, 2006: Simulation of global land surface conditions from 1948 to 2004. Part I: Forcing data and evaluations. J. Hydrometeor., 7, 953 975, doi:10.1175/JHM540.1.

Rabin, S. S., 2016: Investigating the impact of agricultural fire management practices on the terrestrial carbon cycle. Ph.D. thesis, Princeton University, $133 \mathrm{pp}$. [Available online at http://arks.princeton.edu/ark:/88435/dsp01k3569674p.]

Randerson, J., and Coauthors, 2006: The impact of boreal forest fire on climate warming. Science, 314, 1130-1132, doi:10.1126/ science.1132075.

, Y. Chen, G. R. van der Werf, B. M. Rogers, and D. C. Morton, 2012: Global burned area and biomass burning 
emissions from small fires. J. Geophys. Res., 117, G04012, doi:10.1029/2012JG002128.

Rogers, B. M., A. J. Soja, M. L. Goulden, and J. T. Randerson, 2015: Influence of tree species on continental differences in boreal fires and climate feedbacks. Nat. Geosci., 8, 228-234, doi:10.1038/ngeo2352.

Rost, S., D. Gerten, A. Bondeau, W. Lucht, J. Rohwer, and S. Schaphoff, 2008: Agricultural green and blue water consumption and its influence on the global water system. Water Resour. Res., 44, W09405, doi:10.1029/2007WR006331.

Sacks, W. J., B. I. Cook, N. Buenning, S. Levis, and J. H. Helkowski, 2009: Effects of global irrigation on the nearsurface climate. Climate Dyn., 33, 159-175, doi:10.1007/ s00382-008-0445-z.

San Jose, J. J., R. A. Montes, and M. R. Fariñas, 1998: Carbon stocks and fluxes in a temporal scaling from a savanna to a semi-deciduous forest. For. Ecol. Manage., 105, 251-262, doi:10.1016/S0378-1127(97)00288-0.

Schlesinger, W. H., and S. Jasechko, 2014: Transpiration in the global water cycle. Agric. For. Meteor., 189-190, 115-117, doi:10.1016/j.agrformet.2014.01.011.

Staver, A. C., S. Archibald, and S. A. Levin, 2011: The global extent and determinants of savanna and forest as alternative biome states. Science, 334, 230-232, doi:10.1126/science.1210465.

Sterling, S. M., A. Ducharne, and J. Polcher, 2013: The impact of global land-cover change on the terrestrial water cycle. Nat. Climate Change, 3, 385-390, doi:10.1038/nclimate1690.

Thonicke, K., S. Venevsky, S. Sitch, and W. Cramer, 2001: The role of fire disturbance for global vegetation dynamics: Coupling fire into a Dynamic Global Vegetation Model. Global Ecol. Biogeogr., 10, 661-677, doi:10.1046/j.1466-822X.2001.00175.x. , A. Spessa, I. C. Prentice, S. P. Harrison, L. Dong, and C. Carmona-Moreno, 2010: The influence of vegetation, fire spread and fire behaviour on biomass burning and trace gas emissions: Results from a process-based model. Biogeosciences, 7, 1991-2011, doi:10.5194/bg-7-1991-2010.

Tosca, M. G., J. T. Randerson, and C. S. Zender, 2013: Global impact of smoke aerosols from landscape fires on climate and the Hadley circulation. Atmos. Chem. Phys., 13, 5227-5241, doi:10.5194/acp-13-5227-2013.

van der Werf, G. R., and Coauthors, 2010: Global fire emissions and the contribution of deforestation, savanna, forest, agri- cultural, and peat fires (1997-2009). Atmos. Chem. Phys., 10, 11 707-11 735, doi:10.5194/acp-10-11707-2010.

_ , and Coauthors, 2016: Global Fire Emissions Database, version 4s. Global Fire Emissions Database, accessed April 2016. [Available online at http://www.falw.vu/ gwerf/GFED/ GFED4/.]

Wang, H.-J., J. Zhu, and Y.-F. Pu, 2014: Progress and challenge of Earth system modeling (in Chinese). Sci. China Phys. Mech. Astron., 44, 1116-1126, doi:10.1360/SSPMA2014-00155.

Wang, K., and R. E. Dickinson, 2012: A review of global terrestrial evapotranspiration: Observation, modelling, climatology, and climatic variability. Rev. Geophys., 50, RG2005, doi:10.1029/ 2011RG000373.

Wang, Z., J. Chappellaz, K. Park, and J. E. Mak, 2010: Large variations in Southern Hemisphere biomass burning during the last 650 years. Science, 330, 1663-1666, doi:10.1126/ science.1197257.

Ward, D. S., S. Kloster, N. M. Mahowald, B. M. Rogers, J. T. Randerson, and P. G. Hess, 2012: The changing radiative forcing of fires: Global model estimates for past, present and future. Atmos. Chem. Phys., 12, 10 857-10 886, doi:10.5194/acp-12-10857-2012.

Wijngaard, J. B., A. M. G. Klein Tank, and G. P. Können, 2003 : Homogeneity of 20th century European daily temperature and precipitation series. Int. J. Climatol., 23, 679-692, doi:10.1002/joc. 906 .

Yang, J., H. Tian, B. Tao, W. Ren, J. Kush, Y. Liu, and Y. Wang, 2014: Spatial and temporal patterns of global burned area in response to anthropogenic and environmental factors: Reconstructing global fire history for the 20th and early 21st centuries. J. Geophys. Res. Biogeosci., 119, 249-263, doi:10.1002/2013JG002532.

, C. Lu, S. Pan, Y. Wang, and Y. Liu, 2015: Century-scale patterns and trends of global pyrogenic carbon emissions and fire influences on terrestrial carbon balance. Global Biogeochem. Cycles, 29, 1549-1566, doi:10.1002/2015GB005160.

Yue, C., P. Ciais, D. Zhu, T. Wang, S. S. Peng, and S. L. Piao, 2016: How have past fire disturbances contributed to the current carbon balance of boreal ecosystems? Biogeosciences, 13, 675690, doi:10.5194/bg-13-675-2016.

Zeng, X.-D., F. Li, and X. Song, 2014: Development of the IAP Dynamic Global Vegetation Model. Adv. Atmos. Sci., 31, 505514, doi:10.1007/s00376-013-3155-3. 